\title{
Spatial distributions of forms of phosphorus of sediments by use of geographic information systems
}

\author{
Ali Dehbi, Hind Omari, Adil Lammini, Abdelaziz Abdallaoui* \\ University of Moulay Ismail, Faculty of Science, Department of Chemistry, Research Team "Analytical \\ Chemistry and Environment", BP 11201, Zitoune, Meknes, Morocco
}

\begin{abstract}
In Mediterranean countries to semi-arid climate like Morocco, the phenomenon of eutrophication of water bodies is posed with great acuity. The enrichment of water of retaining dam by nutrients, especially phosphorus compounds causing an accelerated growth of algae and higher forms of plant. This development leads to an undesirable disturbance to the equilibrium of organisms present in the water and leads a degradation of the water quality. So it seems particularly useful to seek to determine the various forms of phosphorus bound to sediment and of evaluate in particular the contents of bioavailable forms.

The objective of this work is the study of spatial variations of the different forms of phosphorus sedimentary, such as inorganic forms $\left\{\mathrm{Fe}(\mathrm{OOH})-\mathrm{P}\right.$ and $\left.\mathrm{CaCO}_{3}-\mathrm{P}\right\}$ and organic forms, in the retaining of Sidi Chahed dam (Morocco), as well as the elaboration of spatial distribution maps of these forms of phosphorus by the use of geographic information systems (GIS).

The Thematic maps elaborated by the Geographical Information System (GIS), of the different forms of phosphorus characterizing the environmental condition of the retaining of Sidi Chahed dam, allows to have more accurate distribution of concentrations of forms of sedimentary phosphorus overlying the area of the retaining of dam. The results show that the sediment of plots whose the concentrations of $\mathrm{Fe}(\mathrm{OOH})-\mathrm{P}$ and $\mathrm{CaCO}_{3}-\mathrm{P}$ are inversely proportional, that is that the high sediment concentrations of $\mathrm{Fe}(\mathrm{OOH})-\mathrm{P}$ have less significant concentrations of $\mathrm{CaCO}_{3}-\mathrm{P}$, and vice versa.
\end{abstract}

Keywords - Geographic Information Systems (GIS), Phosphorus, Retaining of Sidi Chahed dam, Sediment, Spatial variations.

\section{INTRODUCTION}

The phosphorus is considered one of the main limiting factors of the primary productivity of freshwater ecosystems. It can lead to eutrophication of the water body [1]. The phosphorus cycle quantification in a lake is related to the concentration of phosphorus stored in sediments. The various forms of phosphorus exist in the solid phase are more concentrated than in the liquid phase.

This chemical element can be put into solution under specific physicochemical conditions and come fertilize the water column [2], [3]. Thus Nürnberg and Peters in 1984 [4], have shown that the sediment represent a significant source of phosphorus for the water of lakes.

Knowing in what form is found the phosphorus in sediments is essential to assess the fraction of phosphorus bioavailable which represent the phosphorus part acceptable to be remitted into solution and can be assimilated by aquatic vegetation.

The objective of this work is the study of phosphorus forms bound to the sediments of retaining of Sidi Chahed dam, and the development of spatial maps of distributions of these forms of phosphorus by the use of geographic information systems.

\section{II.1. STUDY SITE}

\section{MATERIALS AND METHODS}

The retaining of Sidi Chahed dam is located on the Wadi Mikkès, downstream of Wadi Malleh, around $30 \mathrm{~km}$ to the northeast of the city of Meknes and about $30 \mathrm{~km}$ northwest of the city of Fez, on the road main No. 4, linking the latter to the city of Sidi Kacem (figure 1)

The construction of this dam has been destiny primarily at supply the city of Meknes with drinking water. Its capacity is 170 million $\mathrm{m}^{3}$. The watershed of Wadi Mikkès has three structural sets different [5]:

$>$ The plateau of El Hajeb - Ifrane to the south where predominant the carbonate formations whose the fracturing is strong;

$>$ The Saiis basin to the center, constituted by the lacustrine limestones and the tawny sands of the Pliocene as well as the Miocene marl ;

$>$ The pre-Rif north, formed essentially by the marl of Miocene and clays Triassic (figure 2). 


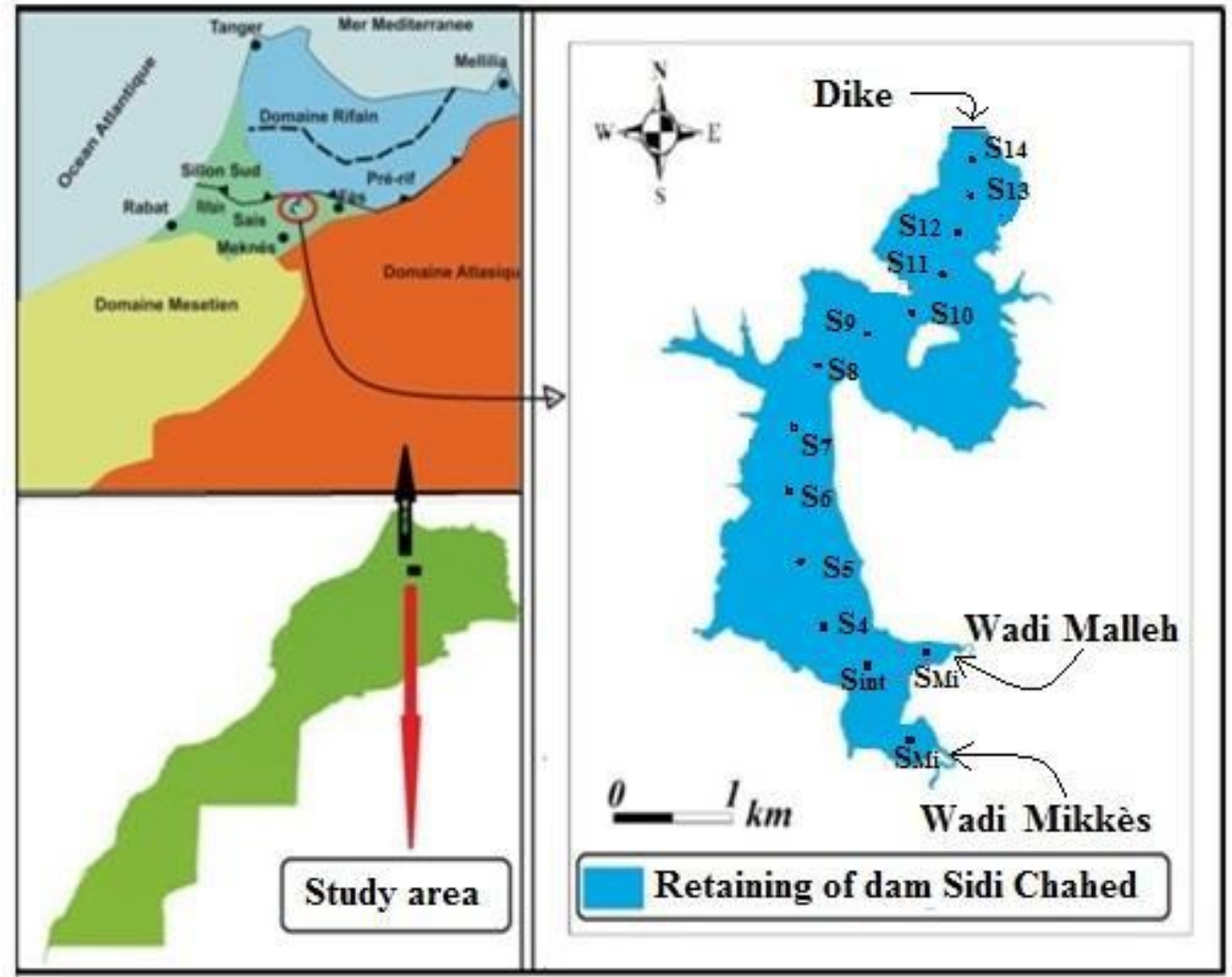

Figure 1: Geographical location of retaining of Sidi Chahed dam and location of sampling stations.

Fourteen sampling stations were retained as part of this study. Including eleven $\left(\mathrm{S}_{4}\right.$ to $\left.\mathrm{S}_{14}\right)$ were chosen spread from upstream to downstream, in order to better cover the entire area of the retaining of dam. These stations are located in the main axis of body of water. The other three were chosen almost of Wadi Malleh, Wadi Mikkès and their intersection. They are noted respectively $S_{\mathrm{Ma}}, \mathrm{S}_{\mathrm{Mi}}$ and $\mathrm{S}_{\mathrm{int}}$.

The surficial sediment samples were performed during four seasons in spring, summer, autumn 2013 and winter 2014, with a grab sampler that allowed taking the first ten centimeters of sediment. Each representative sample of a station is the mixture of three samples from points spaced few meters. The samples are kept in plastic bags in a portable cooler at $4{ }^{\circ} \mathrm{C}$ during transportation to the laboratory where they are processed within 24 hours. All sediments were sifted by wet process. The fraction smaller than 200 microns was retained for analysis, after drying and grinding soft to the mortar to homogenize the sample.

The Speciation of phosphorus in the sediments studied is performed on the fraction less than 200 microns by the EDTA method of Golterman [3] modified and improved to be adapted to the sediments of the retaining of Sidi Chahed dam [6]. The phosphorus concentration is measured by UV at the wavelength of 700 $\mathrm{nm}$ according to the method of ammonium molybdate [7]. The emission spectrometer used is UVmini-1240 type.

The Geographic Information System (GIS) is a system that allows creating, organizing and presenting the spatially referenced alphanumeric data, in other words, geo-referenced [8]. The operating principle is based on a succession of steps allow to produce plans and thematic maps.

\section{RESULTS AND DISCUSSION}

We designate by:

Fe (OOH)-P: phosphorus form bound to iron,

$\mathrm{CaCO}_{3}-\mathrm{P}$ : phosphorus form bound to calcium,

ASOP: form of organic phosphorus soluble in acid,

ROP: $\quad$ form of organic phosphorus residual. inorganic form inorganic form organic form organic form

The results of analysis of the samples studied have shown us that in level of predominance of phosphorus forms bound to sediment, the mineral forms represent nearly $88 \%$ on average of total phosphorus, with the predominance of $\mathrm{CaCO}_{3}-\mathrm{P}$ fraction which represents almost $76 \%$. However, organic forms [ASOP + ROP] represent only $12 \%$ of total phosphorus [6]. This predominance essentially amounts to the geological nature of the terrain. The Simplified geological map shows the great predominance of marl Miocene terrain, very vulnerable to water erosion and landslides especially in the presence of a rugged mountainous terrain [9]. 


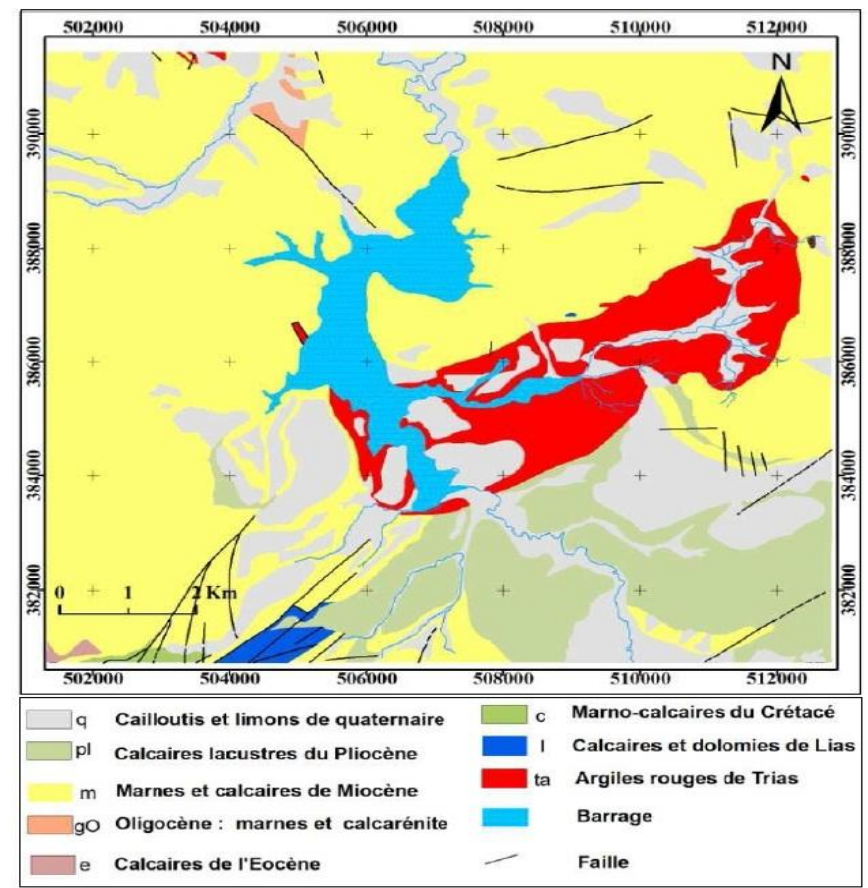

Figure 2: Simplified geological map of the watershed area of the dam Sidi Chahed [9]. phosphate ions.

Before realize thematic maps it is indispensable to give significant intervals of concentrations of Fraction $\mathbf{F e}(\mathrm{OOH})-\mathrm{P}$ : Figure 3 shows that more than half of the retaining area is occupied by sediment whose the concentrations are in the range [65 - 85] mg P / g of sediment, while the concentrations in the range [45-65] $\mathrm{mg} \mathrm{P} / \mathrm{g}$ of sediment, are occupied the remaining area with low numbers and small portions whose the concentrations in the range of [85-106] $\mathrm{mg} \mathrm{P} / \mathrm{g}$ of sediment.

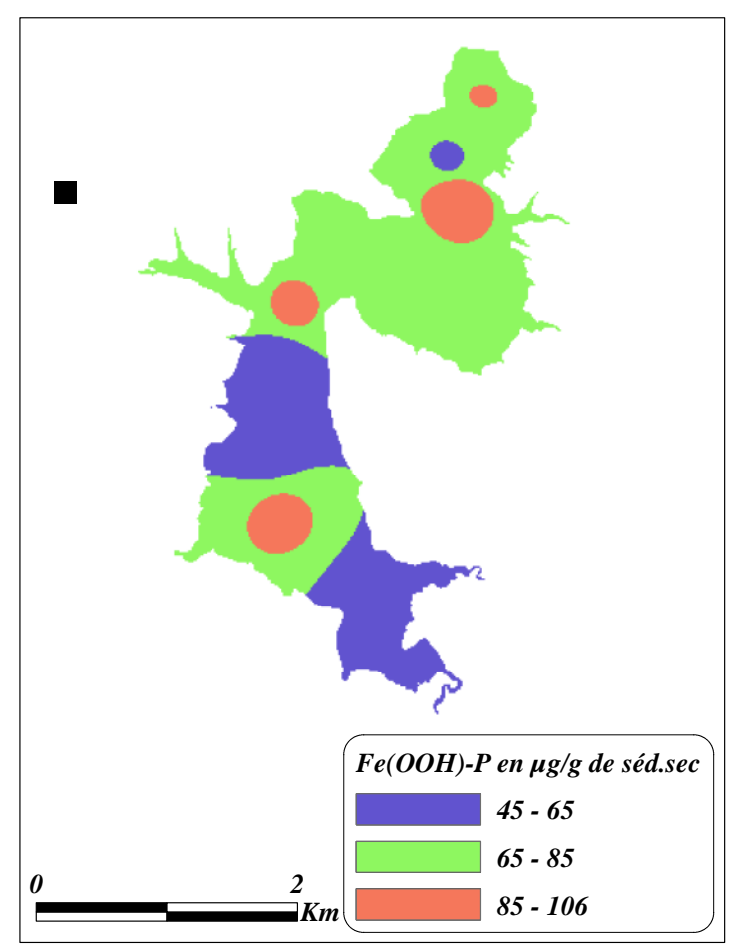

Figure 3: Thematic map of spatial variation of the fraction $\mathrm{Fe}(\mathrm{OOH})-\mathrm{P}$

The high concentrations of phosphate ions in the sediment of these plots are probably due, either by the enrichment of sediments by organic matter either by the absence of the bacterial activity. Conversely, low concentrations are due probably, either by a high bacterial activity either by the low percentages in organic matter. 
According Boer and Van Hese in 1988 [10] and Asuming-Brempong in 2014 [11], the bacterial activity leads to the release of phosphorus bound to iron and therefore a decreased in the concentrations of the latter in the sediment.

Fraction $\mathrm{CaCO}_{3}$-P: The majority of the area of the retaining dam is occupied by sediments with the concentrations are included in the interval [372-429] $\mathrm{mg} \mathrm{P} / \mathrm{g}$ of sediment (figure 4). This result is the response of the calcareous sediment: phosphate ions in the water column are fixed on the carbonates of calcium through the effect of typical alkaline $\mathrm{pH}$ of the water column.

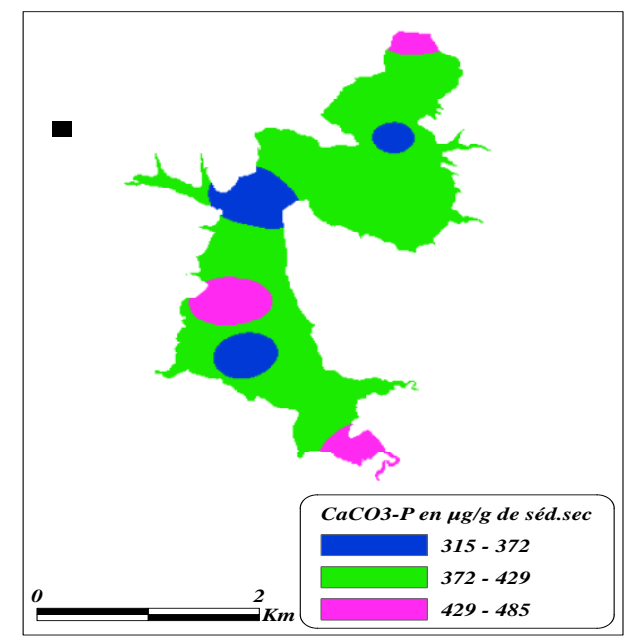

Figure 4: Thematic map of spatial variation of the fraction $\mathrm{CaCO}_{3}-\mathrm{P}$

According to Penn (2000) [12] and House and their collaborators (1986) [13], the $\mathrm{CaCO}_{3}-\mathrm{P}$ fraction is sensitive to variations of $\mathrm{pH}$. An increase in $\mathrm{pH}$ causes the adsorption or co-precipitation of phosphorus with calcium carbonate $\left(\mathrm{CaCO}_{3}\right)$. Conversely, acidic conditions cause the dissolution of carbonates and the release of phosphorus.

The comparison of the two thematic maps concerning fractions of phosphorus bound to iron and that bound to calcium carbonate, shows that the sediments plots including $\mathrm{Fe}(\mathrm{OOH})-\mathrm{P}$ and $\mathrm{CaCO}_{3}-\mathrm{P}$ concentrations are inversely proportional, that is that the high sediment concentrations of $\mathrm{Fe}(\mathrm{OOH})-\mathrm{P}$ have less significant concentrations of $\mathrm{CaCO}_{3}-\mathrm{P}$, and vice versa.

Fraction ASOP: For this form, the area is predominated by the sediments of concentrations which vary between 22 and $41 \mathrm{mg} \mathrm{P} / \mathrm{g}$ of sediment (Figure 5). This form is considered as an available fraction which can be mobilized in the $\mathrm{pH}$ variation [14].

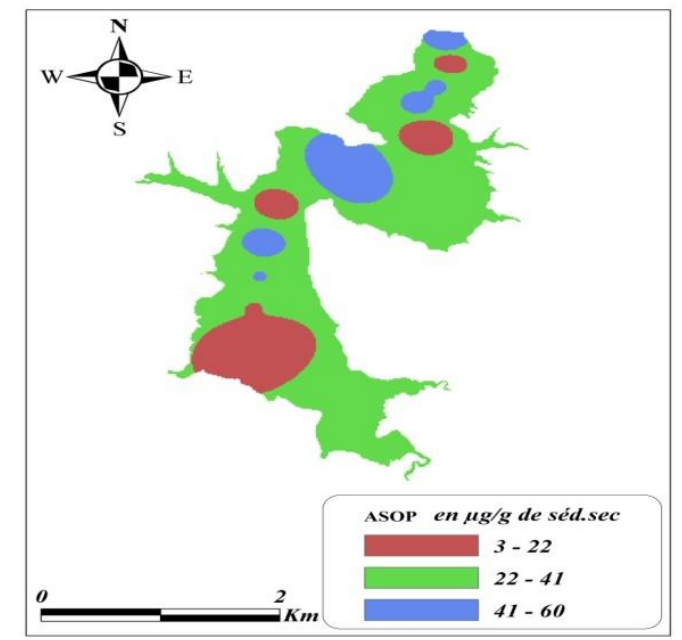

Figure 5: Thematic map of spatial variation of the fraction ASOP

Fraction ROP: Figure 6 shows that half of the area of the retaining Sidi Chahed dam is occupied by sediments, whose the concentration of the residual organic phosphorus varies between 15 and $32 \mathrm{mg} \mathrm{P} / \mathrm{g}$ of sediment, the 
other half includes sediment whose concentration are included between 32 and $49 \mathrm{mg} \mathrm{P} / \mathrm{g}$ of sediment, with small portions of sediment concentrations varying within the range 49 and $65 \mathrm{mg} \mathrm{P} / \mathrm{g}$ of sediment.

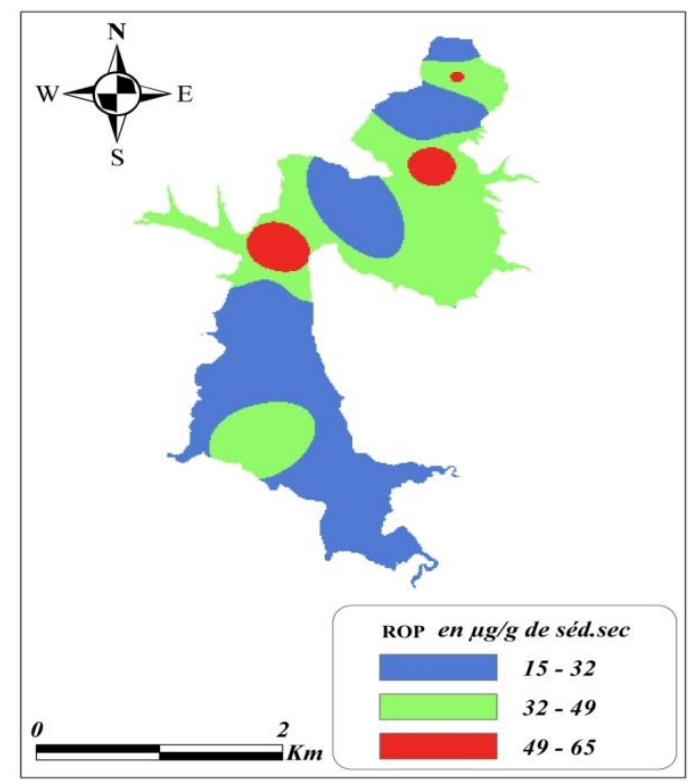

Figure 6: Thematic map of spatial variation of the fraction ROP

This residual organic fraction is formed by phosphorus associated with humic substances such as phytates and phosphonates. Golterman and colleagues showed in 1998 [14] that phytates may disappear from sediments when they become anoxic, and their mineralization may be an important mechanism for anoxic phosphate release from sediments.

\section{CONCLUSION}

We concluded that the study of phosphorus forms in sediments of retaining of Sidi Chahed dam reveals the dominance of inorganic forms; Fraction of $\mathrm{CaCO}_{3}-\mathrm{P}$ being predominant with respect to $\mathrm{Fe}(\mathrm{OOH})-\mathrm{P}$ fraction.Thematic maps elaborated by the Geographical Information System (GIS), of the different forms of phosphorus characterizing the environmental condition of the dam Sidi Chahed, allows to have more accurate distribution of concentrations of forms of sedimentary phosphorus overlying the area of the retaining of dam. Thus they allow us to conclude that the variations of $\mathrm{CaCO}_{3}-\mathrm{P}$ are compensated by the variations of $\mathrm{Fe}(\mathrm{OOH})-\mathrm{P}$ fraction and vice versa

\section{REFERENCES}

[1] D J Conley, H. W. Paerl, R. W. Howarth, D. F. Boesch, S. P. Seitzinger, K. E. Havens, C. Lancelot, and G. E. Likens, Controlling eutrophication: nitrogen and phosphorus, Science, 323, 2009, 1014-1015.

[2] B A Mhamdi, A. Azzouzi, J. Elloumi, H. Ayadi, M. A. Mhamdi, and L. Aleya, Exchange potentials of phosphorus between sediments and water coupled to alkaline phosphatase activity and environmental factors in an oligo-mesotrophic reservoir, Comptes Rendus - Biol., 330, 2007, 419-428.

[3] H L Golterman, Fractionation of sediment phosphate with chelating compounds: a simplification, and comparison with other methods, Hydrobiologia, 335, 1996, 87-95.

[4] G K Nürnberg and R. H. Peters, The importance of internal phophorus load to the eutrophication of lakes with anoxic hypolimnia, Limnol. Oceanogr., 29, 1984, 190-194.

[5] K Belhassan, M. A. Hessane, and A. Essahlaoui, Interactions eaux de surface-eaux souterraines: bassin versant de l'Oued Mikkes (Maroc), Hydrol. Sci. J., 55, 2010, 1371-1384.

[6] A Dehbi, A. Lammini, H. Omari, A. Abdallaoui, and A. EL Hmaidi, Formes de Phosphore dans les Sédiments Aquatiques - Cas de la Retenue du Barrage Sidi Chahed -, Int. J. Innov. Res. Adv. Eng., 1, 2014, 298-305

[7] J. Rodier, B. Legube, N. Merlet, and R. Brunet, L'analyse de l'eau: Eaux naturelles, eaux résiduaires, eau de mer (9ème édition, 2009). 
[8] D Abrid, A. EL Hmaidi, A. Abdallaoui, and A. Essahlaoui, Variation spatiale des concentrations en éléments traces métalliques dans les sédiments de la retenue du barrage Sidi Chahed ( Meknès, Maroc ), Eur. J. Sci. Res., 106, 2013, 503-511.

[9] A El Hmaidi, N. Monyr, M. El Abassi, A. Essahlaoui, A. Abdallaoui, and A. El Ouali, Outils SIG et caractérisation physiographique et climatique du bassin versant du barrage Sidi Chahed ( NE de Meknès , Maroc ), Int. J. Innov. Appl. Stud., 8, 2014, 29-45.

[10] P C M Boers and O. Van Hese, Phosphorus release from the peaty sediments of the Loosdrecht Lakes (The Netherlands), Water Res., 22, 1988, 355-363.

[11] S Asuming-Brempong and N. Aferi, Isolation of phosphate solubilizing bacteria from tropical soil, Glob. Adv. Res. J. Agric. Sci., 3, 2014, 8-15.

[12] M R Penn, M. T. Auer, S. M. Doerr, C. T. Driscoll, C. M. Brooks, and S. W. Effler, Seasonality in phosphorus release rates from the sediments of a hypereutrophic lake under a matrix of $\mathrm{pH}$ and redox conditions, Can. J. Fish. Aquat. Sci., 57, 2000, 1033-1041.

[13] W A House, H. Casey, L. Donaldson, and S. Smith, Factors affecting the coprecipitation of inorganic phosphate with calcite in hardwaters-I Laboratory studies, Water Res., 20, 1986, 917-922.

[14] H Golterman, J. Paing, L. Serrano, and E. Gomez, Presence of and phosphate release from polyphosphates or phytate phosphate in lake sediments, Hydrobiologia, 364, 1998, 99-104. 